Огляди літератури, оригінальні дослідження, погляд на проблему

УДК 616.71-007.234:611.018.4+613.25:616-008.9

DOI 10.11603/1811-2471.2016.v0.i4.7084

\title{
МІНЕРАЛЬНА ЩІЛЬНІСТЬ КІСТКОВОЇ ТКАНИНИ ТА ЧАСТОТА ОСТЕОПОРОЗУ В УКРАЇНСЬКИХ ЖІНОК З МЕТАБОЛІЧНИМ СИНДРОМОМ
}

\author{
ФВ. В. Поворознюк ${ }^{1}$, Л. П. Мартинюк ${ }^{2}$ \\ ДУ «Інститут геронтології імені Д. Ф. Чеботарьова НАМН України» ${ }^{1}$ \\ Український науково-медичний чентр проблем остеопорозу, Київ \\ Двнз «Тернопільський державний медичний університет імені І. Я. Горбачевського моз України», ${ }^{2}$
}

РЕЗЮМЕ. 3 метою визначення частоти остеопорозу (ОП) та низької мінеральної щільності кісткової тканини (МЩКТ) в українських жінок нами було обстежено 1009 осіб, середній вік яких склав $(63,2 \pm 9,0)$ років, а середня маса тіла - $(70,9 \pm 12,3)$ кг. Усі обстежені перебували у постменопаузальному періоді. Пацієнтки були поділені на дві групи. До контрольної групи увійшли 755 жінок без ожиріння (індекс маси тіла $\leq 29,9$ кг/м²). Іншу групу склали 254 пацієнтки з метаболічним синдромом (МС). Групи були зіставними за віком та тривалістю менопаузального періоду.

Оцінку МЩКТ на рівні поперекового відділу хребта, шийки стегнової кістки, передпліччя, всього скелета проводили на двоенергетичному рентгенівському денситометрі (Prodigy, 2005 р.). Діагностику остеопорозу та низької МЩКТ проводили згідно з критеріями офіційної позиції ISCD, 2007 року (переглянуті у 2015 році). Статистичний аналіз проводили за допомогою програми Statistica 6,0.

Нами було проведене порівняння МЩКТ, частоти нормальної, низької МЩКТ та остеопорозу у хворих контрольної групи та пацієнток з МС.

Виявлено, що у хворих з метаболічним синдромом частота остеопорозу та низької МЩКТ є вірогідно нижчою, порівняно з показниками групи осіб без ожиріння.

КЛЮчОВІ СЛОВА: остеопороз, мінеральна щільність кісткової тканини, ожиріння, метаболічний синдром.

Вступ. Метаболічний синдром (МС) - це комплексний стан організму, який, як правило, починає розвиватися після 30 років, його поширеність збільшується у середній віковій групі і досягає максимуму в людей похилого віку [2]. В індустріальних країнах серед населення старшого 30 років поширеність МС складає, за даними різних авторів, 2025 \% [3]. У молодому віці це захворювання частіше зустрічається у чоловіків, а в жінок його частота зростає в постменопаузальному періоді [1].

Основна ідея створення концепції МС полягала у виділенні популяції пацієнтів з високим кардіоваскулярним ризиком, в яких проведення профілактичних заходів, що включають модифікацію способу життя і застосування адекватних лікарських препаратів, може значно вплинути на захворюваність, інвалідність, смертність [10].

У світі активно вивчається зв'язок МС та серцево-судинних захворювань [3] і значно менше робіт щодо впливу метаболічного синдрому на стан кістково-м'язової системи.

Аналіз літератури стосовно зв'язку МС і мінеральної щільності кісткової тканини (МЩКТ) показав протиріччя думок щодо даного питання.

МС включає абдомінальне ожиріння, артеріальну гіпертензію, порушення ліпідного та вуглеводного обміну [10]. Окремі компоненти даного синдрому по-різному впливають на кісткову тканину хворих. Оскільки в жировій тканині відбувається перетворення тестостерону в естрадіол, андростендіону в естрон, посилюється активність остеобластів кістки, які мають рецептори до них, активізується остеобластний остеопоез, то ожи- ріння може мати протекторний вплив на кісткову тканину $[4,9]$. S. S. Fatima та співавт. [8] у своїй роботі також вказали на позитивний вплив ожиріння на МЩКТ. Інші ж автори $[11,12,16]$ доводять, що підвищена маса тіла не завжди має захисний вплив щодо розвитку низької МЩКТ. Так, зокрема, зменшення позитивного впливу маси тіла на кісткову тканину відбувається у період менопаузи, коли зниження секреції статевих стероїдів приводить до стимуляції секреції та посилення активності остеокластів [5].

Порушення вуглеводного обміну характеризується гіперінсулінемією та гіперглікемією. Перша за рахунок стимуляції синтезу колагену в кістковому матриксі, активації ІРФ-1, IPФ-2 сприяє посиленню остеобластного остеопоезу і захисту кістки. Гіперглікемія ж має пряму та опосередковану (шляхом стимуляції глікованими протеїнами синтезу цитокінів) пошкоджуючу дію на клітини кісткової тканини [4].

Окремі дослідники спостерігали кореляцію остеопоротичних змін у постменопаузальний період з індексом атерогенності, рівнями холестерину ліпопротеїдів низької щільності (ХС лПнщ) та холестерину ліпопротеїдів високої щільності (ХС лПВЩ) $[6,14,15,17]$. Результат дослідження Viccica G. та співавт. [18] показав, що рівень XC лПНЩ мав негативну кореляцію з МЩКТ на рівні променевої кістки та поперекового відділу хре6та. Навпаки, рівень ХС ЛПВГ позитивно корелював із МЩКТ у тих же ділянках скелета. Рівень тригліцеридів був значно нижчим у жінок із вертебральними переломами в анамнезі. 
Огляди літератури, оригінальні дослідження, погляд на проблему

Наявність суперечливих даних у літературі щодо зв'язку МС і стану кісткової тканини спонукала нас до даного дослідження.

Метою нашого дослідження було визначення частоти остеопорозу та низької мінеральної щільності кісткової тканини (МЩКТ) в українських жінок з МС.

Матеріал і методи дослідження. Для досягнення поставленої мети ми провели комплексне обстеження 1009 жінок на базі Українського науково-медичного центру проблем остеопорозу. В дослідження включили осіб віком від 45 до 79 років (середній вік становив $(63,164 \pm 8,976)$ роки) в періоді постменопаузи (середня тривалість менопаузи - $(14,577 \pm 8,869)$ роки). Визначали антропометричні показники: зріст (м), масу тіла (кг), індекс маси тіла (IMT), вираховуючи останній за формулою: IMT = маса тіла, кг / зріст, М². Середній зріст обстежених склав $(1,607 \pm 0,065)$ м, середня маса тіла - $(70,940 \pm 12,259)$ кг, IMT - $(27,399 \pm 4,429)$ кг/M². У дослідження не включали жінок, які отримували лікарські засоби або мали захворювання, що впливають на метаболізм кісткової тканини.

Усі пацієнти були поділені на дві групи. До контрольної групи (КГ) увійшли 755 жінок без ожиріння (IMT $\leq 29,9$ кг/M²). 254 пацієнтки іншої групи мали метаболічний синдром. Даний діагноз верифікували відповідно до критеріїв, рекомендованих Міжнародною федерацією з вивчення цукрового діабету [7], згідно з якими, окрім наявності абдомінального ожиріння, яке визначалося за обводом талії (ОТ) > 80 cм, потрібна наявність не менше двох компонентів із 4-х нижче перерахованих: 1) рівень тригліцеридів $\geq 1,7$ ммоль/л або проведення гіполіпідемічної терапії; 2) рівень ліпопротеїдів високої щільності (ЛПВЩ) <1,29 ммоль/л, або хвора отримує специфічну терапію з приводу дисліпідемії; 3) артеріальна гіпертензія (рівень систолічного артеріального тиску (АТ) $\geq 130$ мм рт. ст. i/ або рівень діастолічного АТ $\geq 85$ мм рт. СТ) або проведення антигіпертензивної терапії з приводу раніше діагностованої артеріальної гіпертензії; 4) рівень глюкози в плазмі крові натще $\geq 5,6$ ммоль/л або раніше діагностований ЦД 2 типу. Групи були зіставними за віком і тривалістю менопаузи.
МЩКТ визначали з використанням двоенергетичної рентгенівської абсорбціометрії (DXA) "Prodigy» (GE Medical systems, Lunar, model 8743, 2005 США). Вимірювали сумарний вміст мінералу в досліджуваній ділянці (г), проекційну мінераль-

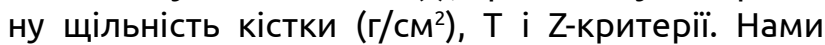
були проаналізовані результати DXA поперекового відділу хребта (L1-L4), шийки стегнової кістки, вертлюга, всього скелета, ультрадистального відділу лівої променевої кістки, 33\% відділу кісток передпліччя та передпліччя в цілому. Показник Т-критерію нижчий від -1,0 стандартного відхилення (CB) розцінювали як низьку МЩКТ (показник від -1,0 до -2,5 СВ свідчив про наявність остеопенії, менше -2,5 CВ - про остеопороз) відповідно до офіційної позиції ISCD [13].

Статистичний аналіз проводили за допомогою програми Statistica 6,0. Результати представлені як середні величини та стандартне відхилення $( \pm \sigma)$. Взаємозв'язок маси тіла та МЩКТ визначали використовуючи лінійну регресію. Різницю між групами визначали за допомогою однофакторного дисперсійного аналізу ANOVA 3 поправкою Шеффе. Оцінку статистичної значимості показників МЩКТ у групах обстежених хворих проводили за допомогою непараметричного визначення критерію $X^{2}$. Різницю показників двох груп вважали вірогідною при показнику $р<0,05$.

Результати й обговорення. У таблиці 1 представлені основні клінічні та антропометричні характеристики пацієнток двох обстежених груп. Середні показники віку та тривалості менопаузи вірогідно не відрізнялися між групами $(p>0,05)$. Середні показники маси тіла та IMT були вірогідно вищими у групі хворих з МС порівняно з контрольною групою $(p<0,001)$. Середні показники зросту у хворих різних груп вірогідно не відрізнялися між собою $(p>0,05)$.

У таблиці 2 представлені показники ліпідограми обстежених пацієнтів. Середні показники рівня холестерину вірогідно не відрізнялися між групами пацієнтів ( $>>0,05)$, тоді як середні показники рівня тригліцеридів та ХСлПНЩ були вірогідно вищими у групі хворих з МС, порівняно з контрольною групою ( $p<0,001$ i $p<0,01$ відповід-

Таблиця 1. Основні клінічні та антропометричні характеристики груп обстежених хворих, $\mathrm{M \pm \sigma}$

\begin{tabular}{|l|c|c|c|c|}
\hline \multicolumn{1}{|c|}{ Групи обстежених хворих } & $\begin{array}{c}\text { Контрольна група } \\
(\mathrm{n}=755)\end{array}$ & $\begin{array}{c}\text { Група з MC } \\
(\mathrm{n}=254)\end{array}$ & $\mathrm{F}$ \\
\hline Вік, роки & $62,955 \pm 9,226$ & $63,783 \pm 8,176$ & 1,620 & $>0,05$ \\
\hline 3ріст, см & $1,608 \pm 0,066$ & $1,604 \pm 0,061$ & 0,958 & $>0,05$ \\
\hline Маса, кг & $66,785 \pm 9,081$ & $83,292 \pm 12,178$ & 523,086 & $<0,001$ \\
\hline IМТ, кг/M ${ }^{2}$ & $25,683 \pm 2,813$ & $32,498 \pm 4,438$ & 811,907 & $<0,001$ \\
\hline Тривалість МП, роки & $14,464 \pm 8,823$ & $14,832 \pm 8,996$ & 0,185 & $>0,05$ \\
\hline
\end{tabular}

Примітка. ІМТ - індекс маси тіла; МП - постменопаузальний період. 
Огляди літератури, оригінальні дослідження, погляд на проблему

Таблиця 2. Показники ліпідограми хворих залежно від групи груп обстежених, $\mathrm{M} \pm \sigma$

\begin{tabular}{|c|c|c|c|c|}
\hline \multirow[b]{2}{*}{ Показник } & \multicolumn{2}{|c|}{ Групи обстежених хворих } & \multirow[b]{2}{*}{$\mathrm{F}$} & \multirow[b]{2}{*}{$\mathrm{p}$} \\
\hline & $\begin{array}{c}\text { контрольна група } \\
(\mathrm{n}=755)\end{array}$ & $\begin{array}{c}\text { група з MC } \\
(n=254)\end{array}$ & & \\
\hline Тригліцериди, ммоль/л & $1,015 \pm 0,349$ & $1,728 \pm 0,718$ & 437,2413 & $<0,001$ \\
\hline Холестерин, ммоль/л & $5,957 \pm 1,131$ & $6,095 \pm 1,151$ & 2,8107 & $>0,05$ \\
\hline ХС ЛПВЩ, ммоль/л & $1,583 \pm 0,393$ & $1,166 \pm 0,275$ & 237,6876 & $<0,001$ \\
\hline ХС лПНЩ, ммоль/л & $3,945 \pm 1,062$ & $4,185 \pm 1,092$ & 9,0805 & $<0,01$ \\
\hline
\end{tabular}

Примітка. ХС лпВЩ-холестерин ліпопротеїдів високої щільності; ХС лпнщ-холестерин ліпопротеїдів низької щільності.

но). Середні показники рівня ХС лПВЩ вірогідно відрізнялися між двома групами пацієнтів також $(p<0,001)$ і були нижчими у 2 групі хворих.

В таблиці 3 наведені результати дослідження стану МЩКТ в групах обстежених пацієнтів. Виявлено, що на усіх досліджуваних рівнях мінераль- на щільність кісткової тканини була вірогідно нижчою в осіб контрольної групи (р<0,001), порівняно з показниками групи хворих з МС.

Нами було проведено регресійний аналіз між масою тіла та показниками МЩКТ поперекового відділу хребта і шийки стегнової кістки у хворих (рис. 1).

Таблиця 3. Мінеральна щільність кісткової тканини у хворих залежно від групи обстежених, $\mathrm{M \pm \sigma}$

\begin{tabular}{|c|c|c|c|c|}
\hline Групи обстежених & $\begin{array}{l}\text { Контрольна група } \\
(\mathrm{n}=755)\end{array}$ & $\begin{array}{c}\text { Група з MC } \\
(\mathrm{n}=254)\end{array}$ & $\mathrm{F}$ & $p$ \\
\hline 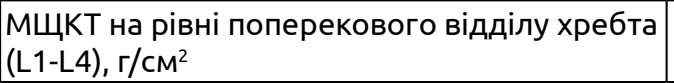 & $0,962 \pm 0,181$ & $1,106 \pm 0,203$ & 112,3014 & $<0,001$ \\
\hline МЩКТ на рівні шийки стегнової кістки, г/см² & $0,795 \pm 0,127$ & $0,874 \pm 0,147$ & 67,1022 & $<0,001$ \\
\hline МЩКТ на рівні вертлюга, г/см² & $0,624 \pm 0,139$ & $0,690 \pm 0,154$ & 40,5603 & $<0,001$ \\
\hline МЩКТ на рівні всього скелета, г/см² & $0,848 \pm 0,142$ & $0,966 \pm 0,157$ & 124,6014 & $<0,001$ \\
\hline $\begin{array}{l}\text { МЩКТ на рівні ультрадистального відділу } \\
\text { лівої променевої кістки, г/см² }\end{array}$ & $0,363 \pm 0,081$ & $0,429 \pm 0,088$ & 119,0553 & $<0,001$ \\
\hline $\begin{array}{l}\text { МЩКТ на рівні 33\% відділу кісток перед- } \\
\text { пліччя, г/см² }\end{array}$ & $0,710 \pm 0,133$ & $0,782 \pm 0,112$ & 60,2539 & $<0,001$ \\
\hline МЩКТ на рівні передпліччя, г/см² & $0,550 \pm 0,104$ & $0,618 \pm 0,095$ & 84,6130 & $<0,001$ \\
\hline
\end{tabular}

Примітка: МщКТ - мінеральна щільність кісткової тканини.

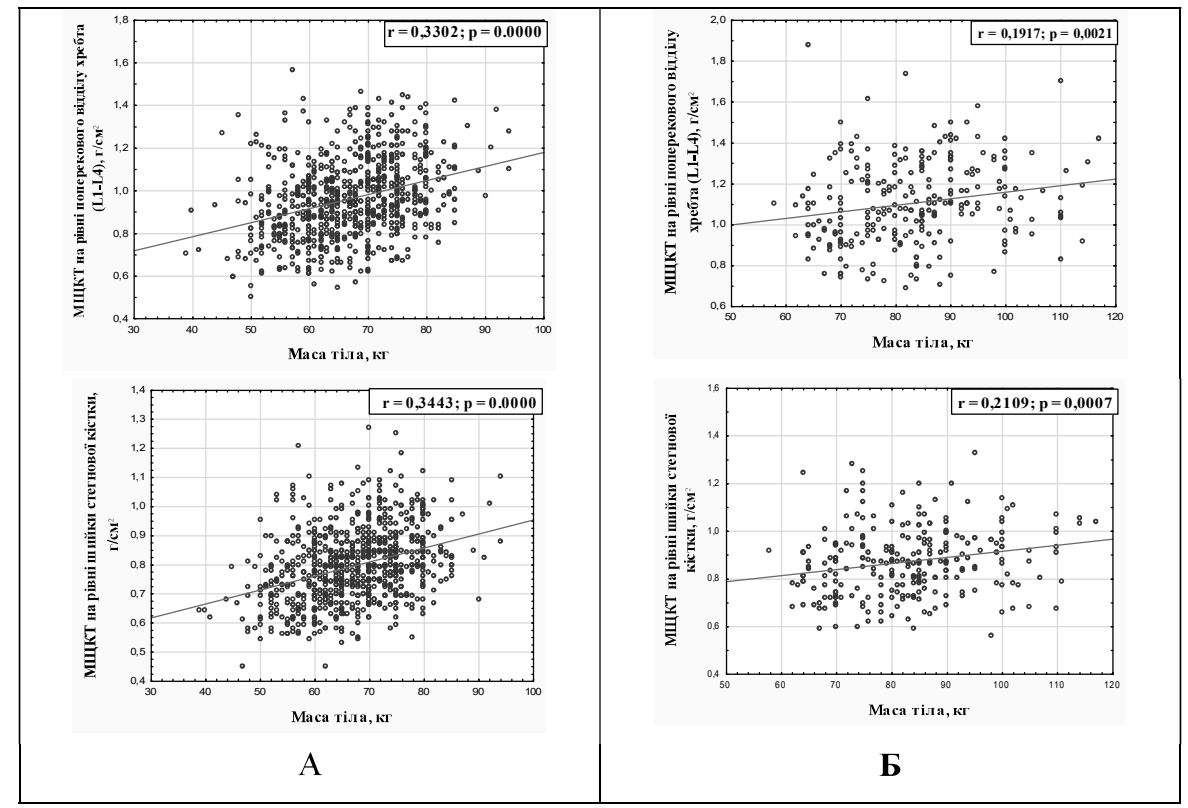

Рис. 1. Регресійний зв'язок між масою тіла та показником МщКТ на рівні поперекового відділу хре6та (L1-L4) та шийки стегнової кістки: А - обстежених контрольної групи; Б - групи хворих з МС. 
Огляди літератури, оригінальні дослідження, погляд на проблему

Регресійний аналіз щодо маси тіла та показників МЩКТ на рівні поперекового відділу хребта (L1-L4) та шийки стегнової кістки в обстежених обох груп хворих виявив вірогідний позитивний зв'язок.

Нами було проведено аналіз впливу рівня тригліцеридів та ХС ЛПВЩ на МЩКТ у пацієнтів (рис. 2, 3).

Виявлено вірогідний позитивний зв'язок між рівнем тригліцеридів і МЩКТ та рівні поперекового відділу хребта (L1-L4) у пацієнтів з MC $(p<0,05)$. Інших вірогідних зв'язків між показника- ми тригліцеридів та ХС лПВЩ і МЩКТ на досліджуваних рівнях у групах обстежених жінок виявлено не було.

За допомогою апарату DXA серед всіх обстежених залежно від групи пацієнтів були виділені жінки з нормальною і низькою МЩКТ (остеопенією та ОП) на рівні поперекового відділу хребта і шийки стегнової кістки. Отримані результати представлені на рисунку 4.

Дослідження МЩКТ поперекового відділу хребта показало, що серед жінок контрольної групи остеопороз зустрічався приблизно у кожної

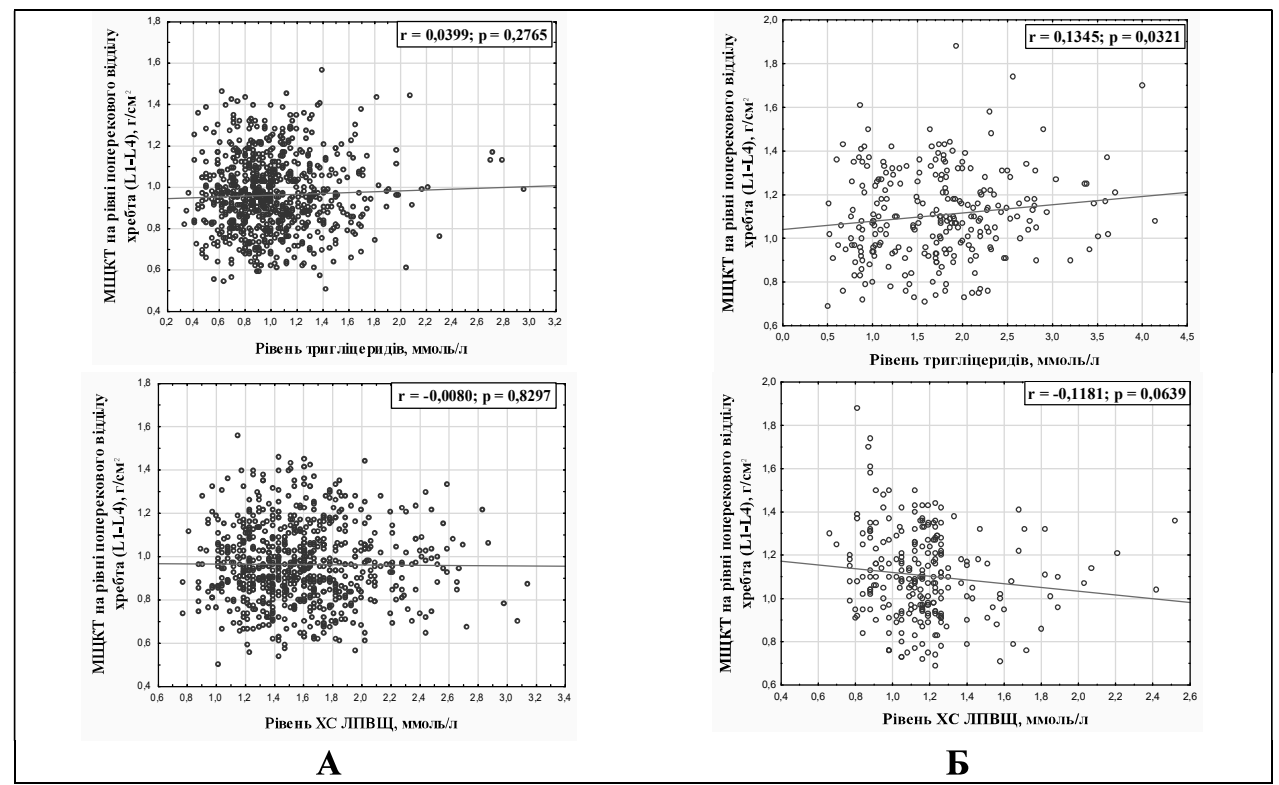

Рис. 2. Регресійний зв'язок між показниками рівня тригліцеридів і ХСлПВщ та показниками МщКТ на рівні поперекового відділу хребта (L1-L4): A - обстежених контрольної групи; Б - групи хворих з MC.

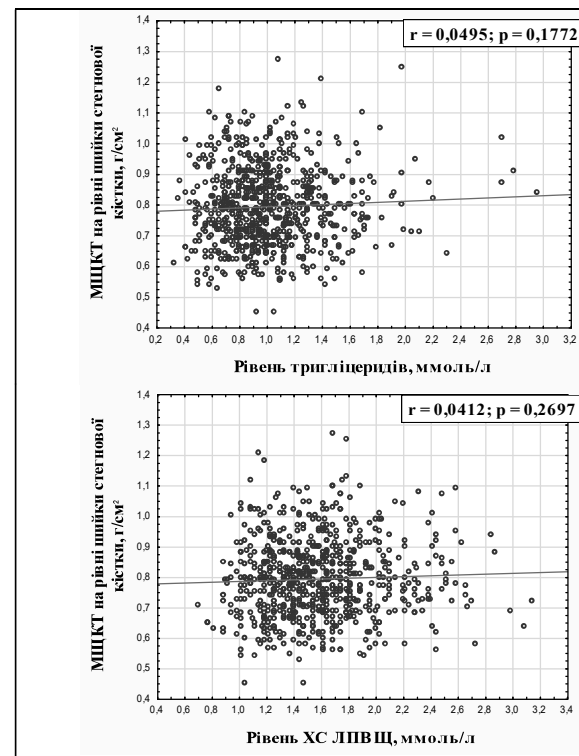

A
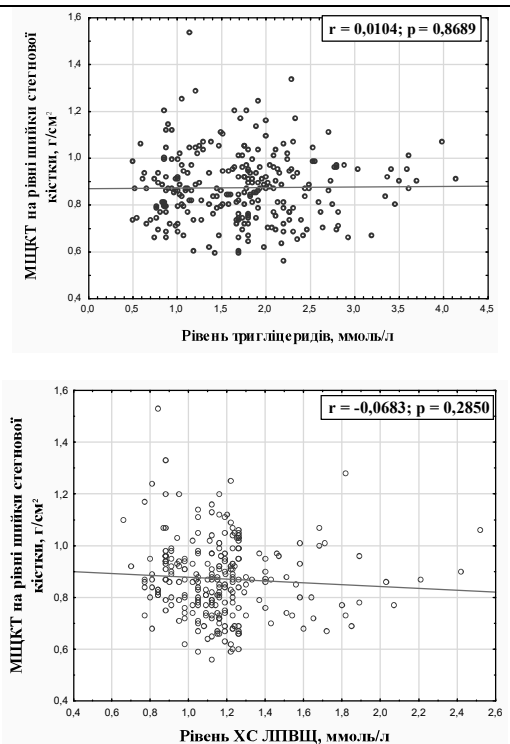

Б

Рис. 3. Регресійний зв'язок між показниками рівня тригліцеридів і ХСлПВщ та показниками МщКТ на рівні шийки стегнової кістки: А -обстежених контрольної групи; Б - групи хворих з МС. 


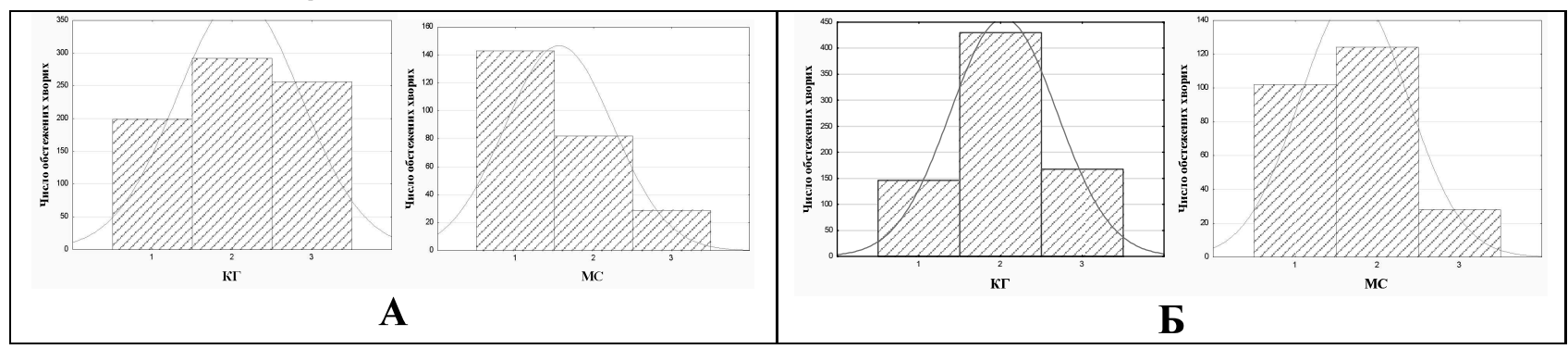

Рис. 4. Частота нормальної МЩКТ, остеопорозу та остеопенії в обстежених хворих: А - на рівні поперекового відділу хребта, Б - на рівні шийки стегнової кістки.

Примітки: 1 - обстежені хворі з нормальною МЩКТ; 2 - жінки з остеопенією; 3 - хворі з остеопорозом; КГ - контрольна група; МС-група хворих з МС.

третьої пацієнтки (34,27\%), тоді як у групі хворих 3 МС його було виявлено в $11,42 \%$ хворих. Нормальні показники стану кісткової тканини мали більше половини осіб групи з МС, що було удвічі більше, ніж у жінок контрольної групи (табл. 4).

Остеопороз в ділянці шийки стегнової кістки зустрічався приблизно вдвічі частіше в осіб контрольної групи, порівняно з хворими групи з МС (табл. 5).

Оцінку статистичної значимості показників МЩКТ у групах обстежених хворих проводили за допомогою непараметричного визначення критерію $X^{2}$.

Порівняння груп пацієнтів показало, що в осіб контрольної групи вірогідно частіше зустрічається знижена МЩКТ на рівні поперекового відділу хребта і шийки стегнової кістки, порівняно з жінками групи з МC $\left(X^{2}=74,13, \mathrm{p}<0,001\right.$ i $X^{2}=42,75, \mathrm{p}$ $<0,0001$ відповідно).

Результати даного дослідження підтвердили літературні дані щодо позитивного кореляційного зв'язку між рівнем тригліцеридів та станом кісткової тканини, зокрема поперекового відділу хребта, у хворих $[6,18]$, а також щодо вірогідного впливу маси тіла на показники МЩКТ [8, 9].

Маса тіла позитивно корелювала із показниками мінеральної щільності кісткової тканини на усіх рівнях, що вивчалися, що може свідчити про протекторний вплив жирової тканини на МЩКТ.

Аналіз частоти остеопорозу та низької МЩКТ в обстежених пацієнтів виявив, що дані показники $є$ вищими у жінок контрольної групи.

Таблиця 4. Частотний розподіл пацієнток з нормальною та зниженою мінеральною щільністю кісткової тканини (остеопенією та остеопорозом) на рівні поперекового відділу хребта залежно від групи

\begin{tabular}{|l|c|c|c|c|}
\hline Групи обстежених & $\begin{array}{c}\text { Норма } \\
(\mathrm{T}>-1 \mathrm{CB}), \%\end{array}$ & $\begin{array}{c}\text { Знижена МЩКТ } \\
(\mathrm{T}<-1 \mathrm{CB}), \%\end{array}$ & $\begin{array}{c}\text { Остеопенія } \\
(\text { Т від -1 до -2,5 CВ), \% }\end{array}$ & $\begin{array}{c}\text { Остеопороз } \\
(\mathrm{T}<-2,5 \mathrm{CB}), \%\end{array}$ \\
\hline КГ & 26,64 & 73,36 & 39,09 & 34,27 \\
\hline МС & 56,30 & 43,70 & 32,28 & 11,42 \\
\hline
\end{tabular}

Примітка. МЩКТ - мінеральна щільність кісткової тканини; КГ - контрольна група; МС - група хворих з МС.

Таблиця 5. Частотний розподіл пацієнток з нормальною та зниженою мінеральною щільністю кісткової тканини (остеопенією та остеопорозом) на рівні шийки стегнової кістки залежно від групи

\begin{tabular}{|l|c|c|c|c|}
\hline Групи обстежених & $\begin{array}{c}\text { Норма } \\
(\mathrm{T}>-1 \mathrm{CB}), \%\end{array}$ & $\begin{array}{c}\text { Знижена МЩКТ } \\
(\mathrm{T}<-1 \mathrm{CB}), \%\end{array}$ & $\begin{array}{c}\text { Остеопенія } \\
(\text { Т від -1 до -2,5 CВ), \% }\end{array}$ & $\begin{array}{c}\text { Остеопороз } \\
(\mathrm{T}<-2,5 \mathrm{CB}), \%\end{array}$ \\
\hline КГ & 19,62 & 80,38 & 57,80 & 22,58 \\
\hline МС & 40,16 & 59,84 & 49,21 & 10,62 \\
\hline
\end{tabular}

Примітка. МщКТ - мінеральна щільність кісткової тканини; КГ - контрольна група; МС - група хворих з МС.

Висновок. У хворих з метаболічним синдромом частота остеопорозу та низької МЩКТ $\epsilon$ вірогідно нижчою, порівняно з показниками пацієнтів групи осіб без ожиріння.
Перспективи подальших досліджень: оцінити вплив окремих компонентів метаболічного синдрому на мінеральну щільність та якість кісткової тканини, вивчити частоту низькоенергетичних переломів у жінок залежно від наявності метаболічного синдрому. 


\section{ЛІТЕРАТУРА}

1. Загайко А. Л. Метаболічний синдром: механізми розвитку та перспективи антиоксидантної терапії : монографія / А. Л. Загайко, Л. М. Вороніна, К. В. Стрельченко. - Х. : Вид-во НФаУ: «Золоті сторінки», 2007. - 216 с.

2. Маколкин В. И. Метаболический синдром / В. И. Маколкин. - М. : ООО «Медицинское информационное агентство», 2010. - 144 с.

3. Мамедов М. Н. Как предупредить риск развития ишемической болезни сердца и сахарного диабета? (Мастер-класс по ведению пациента с метаболическим синдромом) / М. Н. Мамедов // Международный эндокринологический журнал. -2007.- № 5 (11). - С. 47-60.

4. Остеопороз: клиника, диагностика, профилактика и лечение / Н. А. Корж, В. В. Поворознюк, Н. В. Дедух, И. А. Зупанец. - Харьков : Золотые страницы, 2002. $-486 \mathrm{c}$.

5. Поворознюк В. В. Менопауза та остеопороз / В. В. Поворознюк, Н. В. Григор'єва. -К. : Експрес, 2004. - 356 с.

6. Поворознюк В. В. Зв'язок мінеральної щільності кісткової тканини та стану ліпідного обміну у жінок залежно від тривалості постменопаузи / В. В. Поворознюк, О. І. Нішкумай // Проблемы старения и долголетия. -2009 . - Т. 18, № 4. - С. 412-424.

7. Alberti K. G. Definition, diagnosis and classification of diabetes mellitus and its complications: Part 1 : diagnosis and classification of diabetes mellitus provisional report of a WHO consultation / K. G. Alberti, P. Z. Zimmet // Diabet Med. - 1998. - Vol. 15(7). - P. 539-553. PMID:9686693 [PubMed - indexed for MEDLINE].

8. Effect of raised body fat on vitamin $D$, leptin and bone mass / S. S. Fatima, S. Farooq, M. A. Tauni [et al.] // J. Pak. Med. Assoc. - 2015. - Vol. 65(12). - P. 1315-1319. PMID:26627514.

9. Central and peripheral fat body mass have a protective effect on osteopenia or osteoporosis in adults and elderly? Osteoporos Int / P. M. Freitas, M. L. Garcia Rosa, A. M. Gomes [et al.]. - 2016. - Vol. 27(4). - P. 16591663. doi: 10.1007/s00198-015-3414-5. Epub 2015 Dec 9
10. International Diabetes Federation. Worldwide definition of the metabolic syndrome. Available at: http: // WWW.idf.org/web-data/docs/IDF Metasyndrome definition. pdf. Accessd, August 24,2005.

11. Influence of obesity on vertebral fracture prevalence and vitamin D status in postmenopausal women / A. Maghraoui, S. Sadni, A. E. Maataoui [et al.] // Nutr. Metab. (Lond). - 2015. - Vol. 14. - P. 12-44. doi: 10.1186/ s12986-015-0041-2. eCollection 2015. PMID:26583038 [PubMed] PMCID: PMC4650260.

12. Impact of obesity on bone mass throughout adult life: Influence of gender and severity of obesity/L. Maimoun, T. Mura, E. Leprieur [et al.] // Bone. - 2015. - Vol. 1. pii: S8756-3282(15)00421-4. doi: 10.1016/j.bone.2015.11.020.

13.OfficialPositionsofthelnternationalSocietyforClinical Densiometry, Copyright ISCD, October 2007, Supersedes all prior "Official Positions" publications. http://www.iscd. org/official-positions/2015-iscd-official-positions-adult/

14. Papachristou D. J. Bone and high-density lipoprotein: The beginning of a beautiful friendship / D. J. Papachristou, H. C. Blair // World J. Orthop. - 2016. - Vol. 7(2). - P. 74-77. doi: 10.5312/wjo.v7.i2.74. eCollection 2016.

15. Serum lipid levels and bone mineral density in Greek postmenopausal women / P. Pliatsika, A. Antoniou , A. Alexandrou [et al.] // Gynecol. Endocrinol. - 2012 Vol. 28(8). - P. 655660. doi: 10.3109/09513590.2011.650766. Epub 2012 Feb 10.

16. Prevalent osteoporotic fractures in 622 obese and non- obese menopausal women / C. Poiana, M. Carsote, V. Radoi [et al.] // J. Med. Life. - 2015. - Vol. 8(4). - P. 462-466. PMCID: PMC4656953.

17. Associations of lipoproteins with bone mass in postmenopausal women / I. A. Skripnikova, E. S. Abirova, P. A. Alyasova [et al.] // Ter. Arkh. - 2016. - Vol. 88(1). P. 82-88. - PMID:26978615

18. Viccica G. Role of the cholesterol biosynthetic pathway in osteoblastic differentiation / G. Viccica, E. Vignali, C. Marcocci // J. Endocrinol. Invest. - 2007. - Vol. 30(6 Suppl). - P. 8-12. PMID:17721067.

\title{
BONE MINERAL DENSITY AND FREQUENCY OF OSTEOPOROSIS IN UKRAINIAN WOMEN WITH METABOLIC SYNDROME
}

\author{
○V. V. Povoroznyuk ${ }^{1}$, L. P. Martynyuk ${ }^{2}$ \\ D. Chebotoriov Institution of Ukrainian Gerontology Scientific and Medical Center of Osteoporosis Problems, \\ Kyiv, Ukraine ${ }^{1}$ \\ 1. Horbachevsky Ternopil State Medical University ${ }^{2}$
}

SUMMARY. The purpose of the study was to determine the frequency of osteoporosis and low bone mineral density (BMD) in Ukrainian women. The study involved 1009 persons. The mean age of them was $63.2 \pm 9.0$ years; the mean weight was $70.9 \pm 12,3 \mathrm{~kg}$. All women were in postmenopausal period. Patients were compared into two groups. Control group included women without obesity (755 people), another group involved patients with metabolic syndrome (254 people). BMD of lumbar spine, femoral neck, ulna radius, total body was measured by dual-energy X-ray absortiometry, (Prodigy, 2005 уг.). Women were considered to have normal or decreased BMD according to criteria of the Official Positions of the ISCD, 2007 year (updated in 2015 year). Data were analyzed using Statistical Package 6.0 $B M D$, frequency of normal and decreased BMD, osteoporosis were examined in both groups of the patients.

Our study estimated that frequency of osteoporosis and low BMD is much rare in patients with metabolic syndrome compared to women without obesity.

KEY WORDS: osteoporosis, bone mineral density, obesity, metabolic syndrome. 